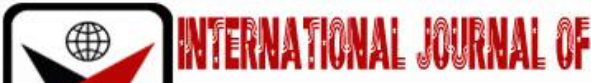

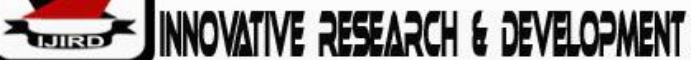

ISSN 2278-0211 (Online)

\section{Evolution of Organisation Theory: A Snapshot}

\author{
Oyibo, Constance 0. \\ Ph.D. Student, Department of Management Sciences, Rivers State University, Nigeria \\ Dr. Gabriel, Justin M. 0. \\ Senior Lecturer, Department of Management, Rivers State University, Nigeria
}

\begin{abstract}
:
This paper is a review and critique of the evolution of organisations theory. Organisations and managers are regularly faced with challenges from the environment of business and these challenges evolve and cause them to shift and adapt regularly and transform themselves to meet the expectations of their clientele. This paper examined the pre-classical, classical, neo-classical and modern theories of organisation to review how they also evolve to meet the needs of the organisation each time. Organizations operate in fluid environments; therefore, it is vital for them to align and re-align their elements and structure in order to survive and compete effectively. We conclude that these theories each have their advantages and flaws but the manager should choose the one that best fits the organization processes per time.
\end{abstract}

Keywords: Pre-classical era, classical organisation theory, neo-classical organisation theory, modern organisation theory

\section{Introduction}

Today's organisations are regularly confronted with numerous challenges arising from its external and internal environments; as such, making optimal decisions under these conditions is a huge concern to managers. Due to these constant challenges, organisations are made to regularly adjust itself and attempt to adapt on a regular basis in order to meet the needs of the environment, survive and prosper. Daft (2010) had averred that organisations encounter rapid changes in the environment arising from the dynamics of globalisation, intense competition, ethical and social responsibility related issues, workplace digitalisation and diversity among others.

The passage of time always alters the challenges faced by organisations, because those of yesteryears are not exactly the same as those of today. Consequently, organisations are not static but change their form regularly. Therefore, as organisations shift and transform themselves to meet the current needs of the environment, organisation theory also evolves to explain the structure, functioning and performance of organizations and the behavior of individuals and groups within it and how the relationship of the organization with the external world impacts it entirely. This paper reviews extant literature on the evolution of organisation theory.

\section{Definition of Organization Theory}

Thomas (2017) defines a theory as a description of phenomenon and the interaction of its variables that are used to attempt to explain or predict it. Similarly, a theory can be described a set of statements that is understandable to others and can be used to make predictions about empirical events. In his earlier attempt, Nicholson (1995) defined organization theory as a series of academic viewpoints which attempt to explain the multiplicities of organizational structure and operating process. Similarly, Zhu (1999) has described organisation theory as a knowledge system that focus on the study and explanations organisational structure, function and operation, including individual and organisational behaviours.

It involves the formation of general ideas and approaches that can be applied by all organizations, no matter their activities, societal and or geographical surroundings (Irefin \& Bwala, 2012). It is the study of the structure, functioning and performance of organizations and the behavior of individuals and groups within it. It is as well concerned with explaining how the relationship of an organization with the external world impacts it entirely.

\section{The Evolution of Organization Theory}

The root of organizations theory can be traced to generalizations on the concept which began as far back as the 1850s, but its origin as a theory can be traced to Gulick's (1937) first formal study of it in 'Notes on the Theory of Organizing.' However, there was not much study carried out on it until the 1950s when Herbert Simon actively promoted the concept with his works on 'Modern Organization Theories' (1950), 'Comments on the Organization Theory' (1952) and 'A Comparison of Organization Theories' (1953). Describing Simon's earlier idea of the concept, Starbuck (2003) asserted that organisation theory is a broad field of study comprising scientific management, industrial psychology, industrial engineering, psychology of small groups, human resources management and strategy among others. 
Organization theories are offshoots of organizational practices and at the same time aid those practices (Yang, Liu \& Wang, 2013). However, theconcept has evolved over time because organisations operate in a fluid environment that causes it to continually change its shape and operations to survive, making organisation theory to evolve along with it to fit its current need. Historic documentations are sketchy on the chronological evolution of organisation theory, especially prior to the pre-classical era. The theory of organisation can be said to have first commenced from the pre-historic age. The prehistoric age is comprised of three eras, including the Palaeolithic (old stone age)-starts with the appearance of first hominids and ends with the discovery of agriculture.

Next is the Mesolithic (middle stone age)- a period of climatic changes when humans learnt to hunt and fish in groups. Thirdly, the Neolithic (new stone age) when humans invented agriculture and livestock raising. The next period is that of management in ancient civilization which was depicted by the Egyptian Pyramid and the Great Walls of China. This period is followed by that of management during the medieval period, a period best known as the era of Darkness. The next period is described as the era of transition which covered the pre-industrial revolution period, industrial revolution period and the pre-scientific period. The last is the era of systematic management which precedes the classical management era. For the purpose of this paper, the evolution of these theories will be broadly categorized and discussed in four phases; Pre-Classical Era, Classical Organizations Theory, Neoclassical Organizations Theory, and Modern organizations theory.

\section{Pre-Classical Era}

Most discussions on the evolution of organisation theory starts with the classical organisation theory, albeit organizations have existed for several years to the effect that management as a concept can be traced to $2900 \mathrm{BC}$ when the Egyptians managed the workplace and built the pyramids (Kitana, 2016). Early philosophers from the pre-classical era advocated conceptual models which later formed the basis on which organisation theories are rooted. These contributors include Robert Owen (1771-1858) who was a pioneer in the field of human resources management and advocated for improved living and working conditions for factory workers. He considered his employees as being equally important as his machines. He was among the first to manage his employees rather than order them and tried to gain their agreement for his ideas rather than imposing it on them. He invented the 'silent monitor' which was used as a means of implementing discipline and reward and is considered a precursor to staff appraisal.

Adam smith (1723-1790) pioneered the concept of management (Kwok, 2014) and identified division of labour and specialisation as major drivers of productivity. He also discovered 'the invisible hand' principle which highlighted the importance of aligning the incentives of labour with the goals of the organisation. Charles Babbage (1792-1871) is considered a giant in the field of operations research and management science. He emphasized the importance of work specialisation and the idea of profit sharing to improve productivity. He invented a mechanical calculator, a versatile computer and a punch-card machine and is considered the father of modern computing. These and other pre-classical contributors presented ideas that became the foundation upon which organisation theories are built.

However, the industrial revolution which resulted in social and technological changes that occurred between mid19th and $20^{\text {th }}$ centuries led to the emergence of larger and more formalized organizations, thus stimulating interest in more people who became involved in organisations (Starbuck, 2003) and this also stimulated interest in more research on the concept resulting in general propositions and theories on it.

\section{Classical Organisation Theory}

This theory was the pioneer theory of organisations and was the traditional theory of organisations in the 1930sand it is still relevant today. The advent of industrial revolution and power -driven machines resulted in production workers and factory systems which led to capital intensive and highly coordinated work processes. As a result, the old order of the organisation process was no longer enough and classical theory emerged as an answer to this challenge. The classical theory comprises three schools of thought comprising the scientific management- which emphasized the one best way to complete a line of work, bureaucratic management- which focuses on hierarchy, rules and procedure, and clear division of labour, and administrative management which emphasized the transmission of information across the organisation.

Classical theorists viewed the organisation as a machine and the humans working in these organisations as the components of this machine. They believed that an organization can only increase its efficiency if its human components are made to be efficient (Onday, 2016). Classical scholars devoted their studies to laying down organizational ideologies and formalization of the structure of the organization.

Contributors to this theory include Adam Smith, Frederick Taylor, Charles Babbage, Max Weber, Daniel McCullum, and Henry Fayol. Smith's division of labour highlighted the positive effects of specialisation with regards to overall productivity of the organisation, while McCullum built on the general principles of smith's organisation and concentrated on the vertical flow of information and designed the first organizational chart (Shafritz, Ott, \& Jang, 2005). Taylor further built on the works of both authors and focused on increasing productivity by using scientific methods to discover the one best way of dividing up task and least fatiguing production method in the design of the organisation.

Weber introduced bureaucracy and defined it as a specific set of structural arrangements, that informed the functionality of organisations (Shafritzet al, 2005). He maintained that bureaucracy is key in the organization and as such there is that need for everyone to accomplish his responsibilities in a hierarchical arrangement (Celik\& Dogan, 2011). He advocated a clear chain of command in the organization and emphasized specialization through division of labour, where employees are to carry out only functions, they are skilled to perform. Performance rewards were tied to competence and merit, objectivity and depersonalization were also encouraged (Pembi, 2019). His work is summarized in the table below 


\begin{tabular}{|c|c|c|}
\hline S/No & $\begin{array}{c}\text { Elements of Bureaucratic } \\
\text { Organisation }\end{array}$ & Explanation \\
\hline 1. & Division of labor & $\begin{array}{c}\text { Jobs designed in a simple, routine, and well-defined } \\
\text { tasks }\end{array}$ \\
\hline 2. & Authority & $\begin{array}{c}\text { Offices or positions are organized to recognize hierarchy } \\
\text { where each lower position is being controlled and } \\
\text { supervised by a higher one. }\end{array}$ \\
\hline 3. & Formal selection & $\begin{array}{l}\text { All staff of the organization are to be selected using } \\
\text { technical qualifications demonstrated by training, } \\
\text { education, or formal examination as yardsticks. }\end{array}$ \\
\hline 4. & $\begin{array}{l}\text { Formal rules and } \\
\text { regulations }\end{array}$ & $\begin{array}{c}\text { To ensure uniformity and to regulate the actions of } \\
\text { employees, managers must rely deeply on formal } \\
\text { organizational rules. }\end{array}$ \\
\hline 5. & Impersonality & $\begin{array}{c}\text { Rules and controls are applied uniformly, avoiding } \\
\text { involvement with personalities and personal } \\
\text { preferences of employees }\end{array}$ \\
\hline 6. & Career orientation & $\begin{array}{l}\text { Managers are professional officials rather than owners } \\
\text { of the units they manage. They work for fixed salary and } \\
\text { pursue their career within the organization. }\end{array}$ \\
\hline
\end{tabular}

Table 1: Max Weber's Bureaucracy

Source: Adapted from Robbins and Coulter (1999). Management. $6^{\text {th }}$ edn

In his case, Henry Fayol (1949) primarily contributed the fourteen principles of management that birthed successful organisations and are still rules managerial processes today. Fayol's 14 principles are hereunder presented in a tabular shape as discussed in Gabriel (2020).

\begin{tabular}{|c|c|c|}
\hline $\mathbf{S} / \mathbf{N}$ & Element of the Principle & Explanations \\
\hline 1 & Division of Work & $\begin{array}{l}\text { Specialization makes it possible for individuals to gather experience, and get } \\
\text { improved in skills for improved productivity. The importance of } \\
\text { specialization is obvious as it enables staff to perform specific tasks not only } \\
\text { at a single time but as a routine duty also (Uzuegbu \& Nnadozie, 2015). }\end{array}$ \\
\hline 2 & Authority & $\begin{array}{l}\text { This implies that the right to issue commands, and authority must go with } \\
\text { responsibility because exercising authority gives rise to responsibility. This } \\
\text { principle suggests that there is a need for managers to have authority in } \\
\text { order to command subordinates so they can perform their jobs while being } \\
\text { responsible for their actions. (Pathak, 2015) }\end{array}$ \\
\hline 3 & Discipline. & $\begin{array}{l}\text { Employees must obey, but this is two-sided: employees will only obey } \\
\text { orders if management plays her part through good leadership. Achinivu, } \\
\text { Okwu, Wey, Akpan, \& Fasan ( } 2017 \text { ) argued that this principle is often a part } \\
\text { of the core values of an organization in form of good conduct, respectful } \\
\text { interactions, proper dress code, etc. }\end{array}$ \\
\hline 4 & Unity of Command & $\begin{array}{l}\text { Each worker should be answerable to one boss with no other conflicting } \\
\text { lines of command. This principle has been however questioned (see } \\
\text { Achinivu, Okwu, Wey, Akpan, \&Fasan, 2017), especially with regards to } \\
\text { current situations in modern organisations where work is done in groups } \\
\text { and teams, it simply suggests that each group will have a coordinator or } \\
\text { supervisor whom orders are gotten from; whereas this coordinator may not } \\
\text { be the sole or overall manager (Uzuegbu \& Nnadozie, 2015). Unuegbu \& } \\
\text { Nnadozie (2015) have further argued that this principle is rigid and needs } \\
\text { modification, especially in consonance with current realities in many } \\
\text { organisations and felt 'Fayol was not explicit to show if it means that only } \\
\text { one person can give orders or whether two or more persons can give } \\
\text { instructions/directives to employees but not at the same time This is as } \\
\text { Nwachukwu (1988) had previously asserted that it is not unusual for a staff } \\
\text { member to receive instructions from superiors outside his/her immediate } \\
\text { units/sections or departments. We could conclude here that Fayol's } \\
\text { proposition is about timing, where only one command is issued at a time. }\end{array}$ \\
\hline 5 & Unity of Direction & $\begin{array}{l}\text { People engaged in the same kind of activities must have the same objectives } \\
\text { in a single plan. This is essential to ensure unity and coordination in the } \\
\text { enterprise. Unity of command does not exist without unity of direction but } \\
\text { does not necessarily arise from it. Organisations run on established } \\
\text { objectives (Drucker, 1954); hence everyone must be committed to the same } \\
\text { direction. }\end{array}$ \\
\hline 6 & $\begin{array}{c}\text { Subordination of individual } \\
\text { interest (to the general } \\
\text { interest) }\end{array}$ & $\begin{array}{l}\text { Management must see that the goals of the firms are always paramount, and } \\
\text { the interest of the employee must be subject to those of the organization. }\end{array}$ \\
\hline
\end{tabular}




\begin{tabular}{|c|c|c|}
\hline $\mathbf{S} / \mathbf{N}$ & Element of the principle & $\begin{array}{l}\text { Explanations } \\
\end{array}$ \\
\hline 7 & Remuneration & $\begin{array}{l}\text { Compensation for work done should be sufficient and fair to both employers } \\
\text { and employees. Fayol suggests that, the significant process of remuneration } \\
\text { paid to employees should be fair, reasonable, satisfactory to both employer } \\
\text { \& employees, and rewarding their efforts (Mtengenzo, 2009). }\end{array}$ \\
\hline 8 & $\begin{array}{l}\text { Centralization (or } \\
\text { Decentralization). }\end{array}$ & $\begin{array}{l}\text { Decreasing the role of the subordinate in decision-making is centralization } \\
\text { whereas increasing such role is decentralization. Fayol believed that } \\
\text { managers should retain final responsibility, but should at the same time give } \\
\text { subordinates enough authority to do their job properly. This is a matter of } \\
\text { degree depending on the condition of the business and the quality of its } \\
\text { personnel. }\end{array}$ \\
\hline 9 & $\begin{array}{l}\text { Scalar chain (Line of } \\
\text { Authority). }\end{array}$ & $\begin{array}{l}\text { A hierarchy is necessary for unity of direction. But lateral communication is } \\
\text { also fundamental, as long as superiors know that such communication is } \\
\text { taking place. Scalar chain refers to the number of levels in the hierarchy } \\
\text { from the ultimate authority to the lowest level in the organization. It should } \\
\text { not be over-stretched and consist of too-many levels. According to Fayol, } \\
\text { 'Organisations should have a chain of authority and communication that } \\
\text { runs from top to bottom and should be followed by managers and the } \\
\text { subordinates.' Scalar chain depicts there should be a clear line of authority } \\
\text { in an organization so that when one sees the need to 'Escalate things' then } \\
\text { you know the line of authority (Bhasin, 2016) }\end{array}$ \\
\hline 10 & Order. & $\begin{array}{l}\text { Both material order and social order are necessary. The former minimizes } \\
\text { lost time and useless handling of materials. The latter is achieved through } \\
\text { organization and selection. This principle however states that every } \\
\text { material in an organization should be put in its right position in the } \\
\text { organization and the right job be assigned to the right employee (Rodrigues, } \\
\text { 2001). }\end{array}$ \\
\hline 11 & Equity. & $\begin{array}{l}\text { In running a business, a 'combination of kindliness and justice' is needed. } \\
\text { Treating employees well is important to achieve equity. The principle of } \\
\text { equality should be followed and applied at every level of management. Thus, } \\
\text { there should not be any form of discrimination as regards status, sex, } \\
\text { religion, etc. (Okpara, 2016). Fairness can be said to be in similar context } \\
\text { with Equity. According to (Mtegenzo, 2009), Equity means combination of } \\
\text { fairness, kindness \& justice towards employees. It simply means for } \\
\text { commitment and loyalty to be expected from employees, they should be } \\
\text { treated fairly and similarly to people of their level of position and authority, } \\
\text { most importantly, their Managers should be less impartial. }\end{array}$ \\
\hline 12 & $\begin{array}{l}\text { Stability of Tenure of } \\
\text { Personnel }\end{array}$ & $\begin{array}{l}\text { Employees work better if job security and career progress are assured to } \\
\text { them. An insecure tenure and a high rate of employee turnover will affect } \\
\text { the organization adversely }\end{array}$ \\
\hline 13 & Initiative & $\begin{array}{l}\text { Allowing all personnel to show their initiative in some way is a source of } \\
\text { strength for the organization. Even though some mistakes may arise in the } \\
\text { process, the gains are surely more. However, there should always processes, } \\
\text { procedures and policies in place to guide the employees to ensure successful } \\
\text { implementation and prevent abuse of the privilege as managers encourage } \\
\text { initiative (Okpara, 2015). }\end{array}$ \\
\hline 14 & Esprit de Corps & $\begin{array}{l}\text { According to Merriam Webster, espirit de corps is the common spirit } \\
\text { existing in the members of a group and inspiring enthusiasm, devotion, and } \\
\text { strong regard for the honor of the group. William et al. (2005) describes it as } \\
\text { the degree to which employees obliged to common goal and to one another } \\
\text { in the organization. Similarly, (Homburg et al., 2002) described as 'valued } \\
\text { asset among organizational members who do not have formal authority over } \\
\text { each other'. Espirit de Corps is the intensity and depth of feelings which } \\
\text { brings job and fosters support amongst members of a group (Boyt, et. al. } \\
\text { 2005). }\end{array}$ \\
\hline
\end{tabular}

Table 2: Fayol's 14 Principles of Management

Source: Adapted from Gabriel, J.M.O. (2020): Principles and practice of management for successful business (in press).

These great men developed their theories by building on each other's work and viewed organisations as machines that require boundaries between units. They relied on the predictability and accuracy achieved via specialisation, the vertical flow of information and limited exchanges with the external environment (Kuk, 2012).

This theory placed emphasis on specialization and co-ordination of the activities of the production process. It was mainly concerned with the one best way of dividing up task to be done, how to group these tasks together into departments and with the coordination of the production process. They emphasized the need for a clear definition of responsibilities and authority and they also explained the principles that should be used in designing the organisation. The six pillars of this theories are departmentalisation, division of labour, scalar and functional process, coordination, structure and span of control (Onday, 2016).

The following are some basic assumptions of these theories: (Shaftritz, et al, 2005);

- Organizations are formed to implement production related and economic goals. 
- There is one best way to organize the production process and that best way can be found by a systematic scientific inquiry.

- Workers, as components of the organisational machine, are replaceable.

- Through division of labour and specialisation, production can be maximized.

- The organisation and its people are rational economic beings.

- Organisations should function like machines

- Organisations should be structured into departments.

\subsection{Criticisms}

The major criticism of this school of thought is that there were very few experiments and administrative observation for trying the viability of the philosophies and propositions projected in it (Ivanko, 2013), as a result, most of its assumptions have been roundly criticized. Another criticism is that they viewed the organization as a closed system that does not interact with its environment as they focused mainly on the structural and technological aspects of it (Onday, 2016), however, it can no longer be denied that organizations are open systems that interact with their environment. Its assumptions are oversimplified and mechanistic and views the organization as a machine without people. People are seen as a means to an end and the theory does not care about the feelings of workers in carrying out their job, neither does it give them room to contribute to improving their job functions (Onday, 2016). Consequently, it does not explain fully the behavior of humans in organizations, and thus it cannot adequately deal with the complexities of an organization structure and functioning. Even though organizations want to be more efficient through standardization of skills and methods, it cannot expect a standard and emotionless behavior from its workforce (Bowditch, Buono\& Stewart, 2008).Another major limitation is the lack of flexibility in the application of bureaucracy with regards to multi-tasking and team work which are relevant in today's organization (Pembi, 2019). This theory is considered obsolete (Onday, 2016).

\section{Neo-classical Organization Theory}

The increase in output and the educational development of employee coupled with the excessively severe principles and mechanical models of organization, the classical theories of organization resulted in regular confrontations and tension between the workforce and management, the inner communications are responsible for being misunderstood and the inner clashes become, to a greater extent, common (Ferduous, 2017). Consequently, studies were carried out to examine and identify the causes of these unpleasant outcomes. It is these studies that will inspire the new theories of administration that would pay more consideration to the human issue and birth the humanized organization (Yang et al, 2013).

Elton Mayo pioneered the Hawthorne studies which formed the basis for this theory. The study started in 1924 at Hawthorne works, the western electric company in Chicago. He did several experimentations using diverse approaches to investigate the relationship between the style of leadership, working condition and other organizational issues with employee output. The study revealed that economic incentives alone is not enough to keep human beings motivated, hence social and psychological motivating factors which include appreciation, association, sense of belongingness and different societal facets connected to the workplace were discovered (Kashyap, 2015). It was discovered that there are informal organisations within the organisation and that socio-psychological factors exert influence on human behaviour. It showed the possibility that co-workers may exert a greater influence on work behaviour than the economic incentives offered by management (Onday, 2016). This revelation that the workers are social beings and have social needs contradicted the classical theory's position that viewed people solely as rational, economic creatures. Social considerations were now seen as the prime motivator of behavior and work performance.

There are two main sources of neoclassical theory: the sociologists and social psychologists who were concerned with interaction and relations within groups, often referred to as the Human Relations School, and the psychologists who focused on individual behaviour, or the Behavioural School. Some basic assumptions of the theory are a view of the organisation as a social system that has several integrating parts. It recognises the existence of an informal organisation within every formal organisation and that both of them affect each other. The theory assumes that the human being is interdependent, therefore, the organisation can only predict its behaviour if it studies its social and psychological factors. It posits that human beings do not always act rationally, and that organisation goals conflict with the goals of the individual workers, therefore, it is important to reconcile these goals to benefit both parties.

This theory has vitally influenced the consideration of human behaviour on the job and in the organization. It has highlighted the vast role of the human being in the production process (Ferdous, 2017), and has given fresh thoughts and practices for a better understanding of human behaviour with regards to group dynamics, team work, culture, leadership, motivation, group dynamics, participation, the environment of the job, and power and influence. According to Chakrabarty and Chand (2012), the four major pillars of this theory are scalar and functional procedures, the division of labour, span of control, and structure.

Other contributors to this theory include Abraham H. Maslow, Frederick Herzberg, Douglas Mc Gregor, Rensis Likert, and Keith Davis who all worked to inspire and promote the drive forhuman relations, which posit that workers react mainly to the societal setting of the workplace, containing societal habituation, group customs and relational dynamics (Sarker\& Khan, 2013).

\subsection{Criticisms}

The neoclassical theory has its own limitations. Firstly, its assumptions do not have scientific legitimacy and suffer from an experimental partiality, and its conclusions are uncertain (Ferdous, 2017). Another limitation is that its use, in 
reality, is very difficult as it necessitates essential modifications in the philosophy and approach of both administration and workforces (Sarker \& Khan, 2013). Also, the theory is just a modification of the classical theory and as such, lacks a unified approach. It began as an idea to compensate for the lack of human interactions in the classical era. The Hawthorne study also failed to show any significant correlation between workplace conditions and productivity.

\section{Modern Organisation Theory}

Modern organisation theory is an integration of valuable concepts of the classical models with the social and behavioural sciences. Modern theorists view the organization as a dynamic open system which has to adapt to changes in its environment. This theory still has a major influence in contemporary society. Its distinctive features are its reliance on empirical research data, conceptual-analytical base, and, more importantly, it's integrating nature (Ferdous, 2017). These distinct features are inspired by a philosophy that accepts the premise that the only meaningful way to study organization is to study it as a system. It treats the organization as a system of mutually dependent variables. The organization has reflected a sub-system which happens and interrelates within a much comprehensive system (Abdullah, 2012). Consequently, modern organization theory, which accepts system analysis, changes the conceptual level of organization study above the classical and neoclassical theories. This theory asks a range of interrelated questions which are not seriously considered by the two other theories (Onday, 2016).

This theory is not unified body of thought, as each contributor has his own special part where he places emphasis when he considers the system. It is an amalgamation of contingency, decision-making, systems and other theories, According to Onday (2016), the parts of the organisational system comprise the individual and the personality structure he brings to the organisation, the formal arrangement of functions, that is, the organisational structure, the informal organisation, the physical setting in which the job is to be accomplished and the status and role patterns and all these parts are interrelated and work together to achieve organisational goals. These subsystems are interconnected through communication, decision-making, and balance which is the equilibrating mechanism which allows the different parts of the system to stay in a harmonious and structured relationship.

Other distinguishing features of this theory are that it is probabilistic and not deterministic as its results are uncertain and depends on the chance of occurrence. It emphasises the importance of communication and integration of individual and organisational interest as a basis for smooth functioning of the organisation. It encompasses multi-level and multi-dimensional aspects of the organisation, as it covers both the internal and external environment of the organisation. Another distinguishing feature is that this theory is multi-variable; it considers multiple variables simultaneously, showing that cause and effects are not simple phenomena but can be caused by a combination of several variables (Chakrabarty \& Chand, 2012).

\subsection{Criticisms}

This organisational theory is not unified but a blend of several theories like the systems theory, contingency theory, decision making theory, etc. It is too abstract to be of much practical use and does not specify the precise relationship between the organisation and the social system. This theory is not really modern but is based on the research of earlier theories. More importantly, it does not offer a framework which can be applied to all organizations.

\section{Conclusion}

The early philosophers from the pre-classical era advocated conceptual models which later formed the foundation on which organisation theories are built when the social and technological changes brought on by the industrial revolution necessitated the emergence of organisation theories. The classical organisation theory is the pioneer organisation theory and it made enormous contributions to the practice of management but it did not always yield desired results. It's oversimplified and mechanistic view of the organization as a machine without people could no longer adequately deal with the complexities of an organization structure and functioning as factories became larger. The neo-classical organisation theory came with another perspective to make-up for the perceived lack in classical theory but it also has its own flaws. New challenges are springing up, with global pandemics, globalisation, and technological advances, on the rise, organisations are adapting in response to these challenges in the environment. There is a rise in new perspectives and ideologies as organisations become increasingly larger and complex thus the bureaucratic organisation is also giving way to matrix structures. Thus, modern organisation theory is gradually replacing bureaucratic organisations, however, it is our opinion that classical and neo-classical theories are still important and cannot be completely done away with as they still provide very relevant answers to certain challenges.

\section{References}

i. Abdullah, M. M. (2012). Public administration. Dhaka: Jahan Publications.

ii. Achinivu, G, Okwu, E. H, Wey, A. A., Akpan, E. E. Fasan, O. J. (2017). Application of the Henri Fayol Principles of management in start-up organizations IOSR Journal of Business and Management (IOSR-JBM) 9(10), 78-85

iii. Anderson, D. I. (2017). Organisation development: The process of leading organisation change. London: Sage Publication.

iv. Barnard, C. I. (1938). The functions of the executive. Cambridge, MA: Harvard University Press.

v. Bowditch, J. L., Buono, A. F., \& Stewart, M. M. (2008). A primer on organizational behavior. (7th ed). Hoboken, N. J.: John Wiley and Sons, Inc.

vi. Boyt, T., Lusch, R., and Mejza, M. (2005). „Theoretical Model of the Antecedents and consequences of organizational, workgroup and Professional esprit de Corps'. European Management Journal, 23(6): 682-701 [6]. 
vii. Celik, M., \& Dogan, E. (2011). A theoretical approach to the science of management. International Journal of Humanities and Social Science, 1 (3).

viii. Chakrabarty, B. \& Chand, P. (2012). Public administration in a globalizing world: Theories and practices. New Delhi: Sage Publications.

ix. Chikere, C. C., \&Nwoka, J. (2015). The system theory of management in modern day organisations: A study of Aldgate Congress Resort Limited, Port Harcourt. International Journal of Scientific and Research Publications, 5, 1-7.

x. Daft, R. L. (2010). Organisation theory and design (10thEd.). South-Western: Cengage Learning.

xi. Drucker, P. (1954). The practice of management. New York: Harper \& Row. [7].

xii. Fayol, H. (1949). General and industrial management (C. Storrs, Trans.). London: Sir Isaac Pitman \& Sons.

xiii. Ferdous, J. (2016). Organizational theory from classical perspective. International Journal of Economics and Law, $9(2), 1-6$.

xiv. Gulick, L. H. (1937). Notes on the theory of organizations. In Luther H. Gulick and Lyndall F. Urwick (eds), Paper on the science of administration. New York: Institute of Public Administration, Columbia University.

xv. Irefin, M. P., \&Bwala, D. (2012). Organizational theories and analysis: A feminist perspective. International Journal of Advancements in Research and Technology, 1(1), 71-97.

xvi. Ivanko, S. (2013). Modern theory of organization. University of Ljubljiana, Faculty of Public Administration.

xvii. Kitana, A. (2016). Overview of the managerial thoughts and theories from the history: Classical management theory to modern management theory. Indian Journal of Management Science VI(1), 16-21.

xviii. Kwok, A. C. F. (2014). The evolution of management theories: A literature review. Nang Yan Business Journal, $3(1), 28-40$.

xix. Kuk, I. (2012). The changing nature of student affairs. In Ashley Tull and Linda Kuk (Eds.). New realities in the management of student affairs: Emerging specialist roles and structure for changing times. Sterling, VA: Stylus.

xx. Onday, 0. (2016). Classical to modern organisation theory. International Journal of Business and Management Review, 4(2), 14-49.

xxi. Okpara, F. C. (2016) Henri Fayol's 14 Principle of management and it's applications to a Bank. Retrieved from amazon.com

xxii. Pathak, R. (2014) Principle: Authority and Responsibility. Management Diary. Retrieved from amazon.com

xxiii. Pembi, S. (2019). Relevance of management thoughts and ideas to private sectors in Yola, Adamawa State. Global Scientific Journals, 7(5), 311-324.

xxiv. Nicholson, N. (1995). Blackwell encyclopaedic dictionary of organizational behaviour. Blackwell: Oxford.

xxv. Nwachukwu, C. C. (1988). Management: Theory and practice. Ibadan, Nigeria: Africana-Feb Publishers.

xxvi. Sarker, S. I., \& Khan, M. R. (2013). Classical and neoclassical approaches of management: An overview. IOSR Journal of Business and Management, 14 (6), 1-5.

xxvii. Shafritz, J. M., Ott, J. S., \& Jang, Y. S. (2005). Classics of organization theory.(6 ${ }^{\text {th }}$ Ed.), Belmont, CA: Wadsworth.

xxviii. Thomas, J. E. (2017). Scholarly views on theory: Its nature, practical application, and relation to world view in business research. International Journal of Business and Management 12(9), 231-239.

xxix. William, D. R, Swee-Lim, C., and Cesar M. (2005). Job insecurity spill over to key account management: Negative effects on performance, effectiveness, adaptiveness, and esprit de corps, Journal of Business and Psychology, 19 (4), 483-503

xxx. Yang, C. X., Liu, H. M., \& Wang, X. X. (2013). Organization theories: From classical to modern. Journal of Applied Sciences, 13 (21), 4470. 